Vol. 45 , p. 55, 1953

\title{
ENZYMIC PHOSPHORYLATION OF GALACTOSAMINE AND GALACTOSE ${ }^{1}$
}

\author{
By C. E. Cardini and L. F. Leloir \\ Instituto de Investigaciones Bioquimicas, Fundación Campomar \\ Julián Alvarez 1719, Buenos Aires, Argentina
}

\section{INTRODUCTION}

Harpur and Quastel ${ }^{1}$ observed that glucosamine is phosphorylated on incubation with brain extracts and adenosine triphosphate (ATP), and that glucose acts as a competitive inhibitor. From further study by Brown ${ }^{2}$ and by Grant and Long ${ }^{3}$ of this phosphorylation, using purified yeast hexokinase, it has been concluded that glucose and glucosamine phosphorylation are catalyzed by the same enzyme.

In the course of studies on hexosamine metabolism, it was observed that crude extracts of liver, and also of brain, catalyze a transference of phosphate from ATP to galactosamine. After partial purification of the liver enzyme, the phosphorylation of galactose could be clearly detected. The latter process is difficult to study with crude extracts, but a small activity had been reported by $\mathrm{Ba}$ cilas.

An extract containing an enzyme catalyzing the phosphorylation of galactose (galactokinase) can be obtained from yeast ${ }^{5-6}$ and is more active than that of animal tissues. Therefore, it was tested with galactosamine as substrate. Phosphorylation was found to take place, and the extracts of yeast adapted to galactose were found to be more active than those from nonadapted yeast.

\section{EXPERIMENTAL}

\section{Liver Enzyme}

An adult rat was fasted for $36-48 \mathrm{hr}$. The liver

1 This investigation was supported in part by a research grant (G-3442) from the National Institute: of Health, U. S. Public Health Service; and by the Rockefeller Foundation. (about 0 g.) was washed with ice water and homogenized in 2 vol. of $1 \%$ potassium chloride. The homogenate was then. centrifuged in the cold for 15 $20 \mathrm{~min}$. at 15,000 r.p.m. The supernatant was filtered through cotton wool to remove the floating fatty material. Half a volume of saturated ammonium sulfato solution was added, and the mixture was centrifuged and filtered as in the previous step. Half a volume of saturated ammonium sulfate was again added to the supernatant, and after centrifugation the precipitate was dissolved in $1.5 \mathrm{ml}$. of distilled water and dialyzed for about $2 \mathrm{hr}$. in the cold. The protein content of these extracts was about $70-80 \mathrm{mg} \cdot / \mathrm{ml}$.

Extracts from nonfasted rats could be used for measuring galactosamine phosphorylation, but not for that of gilactose because a considerable amount of reducing substances was liberated during incubation. After fasting, this blank was greatly reduced or suppressed in some cases.

\section{Brain Enzyme}

Rat brains were homogenized in $10 \mathrm{vol}$. of cold acetone. After washing with acetone and ether, the extract was allowed to dry at room temperature. The dry powder (500 mg.) was homogenized in $3 \mathrm{ml}$. of $0.06 M$ disodium phosphate. After $30 \mathrm{~min}$. in the cold, the mixture was centrifuged and the precipitate rejected.

\section{Yeast Enzyme}

Saccharomyces fragilis was grown in yelast extract. agar containing $2 \%$ glucose or lactose. The cells were harvested after $48 \mathrm{hr}$. at $30^{\circ}$, washed, extended in 2 $\mathrm{mm}$. layers, and allowed to dry in air. After 3-4 days, the dry material was extracted at $5^{\circ}$ as described by Neuberg and Lusing (7). The protein content was then adjusted to about $70 \mathrm{mg} \cdot / \mathrm{ml}$.

\section{Substrates}

Galactosamine was prepared as described by Levene (8) from hogs' nasal septa. Adenosine triphosphate was obtained according to Needham (9).

\section{Analytical Methods}

Galactosamine was estimated by the method of Elson and Morgan as described by Blix (10). Other methods were as follows Roe (11) for fructose; Fis- 
he ame sublodRow (J2) for phosphate; Kunitz and liclonald (13) for protein; Somogyi (I4) and Nelson (15) for reducing sugars. The amount of sugar phesphorvlated was measured by precipitating the proteins and phosphoric esters with $0.3 \times$ barium hvdroxide and $5 \%$ zinc sulfate (5, 14). Either 0.2 of $19.4 \mathrm{ml}$. of each solution was used for the test system as described in Table I. The difference in free sugar between the incubated and nonincubated samples was comsidered to be due to phosphorylation. Paluhs without added sugar or $17 \mathrm{P}$ were run in wimle caues.

In aldernative method was used in the experimont shown in Fig. 3. In this case the formation of gallactosamine esterified was mosured instead of the disatplearance of free galactosamine. The phosphoric esters were precipitaterl with zinc sulfate and barium hodroxide, the precipitate was washed, and then the galactosamine phosplate was hydrolyzed with acid and the galactosamine was estimated as ustat. This procedure is more baborious than the other and can only be applied when the reaction product is the 1-ester. but it bas the advantage that ii. can be used even with high sugar concentrations.

the details were as follows: The reaction mixture wats ats shown in Fig. 3. I blank with no substrates and another without incubations were run at the same time. The reaction was stopped by adding (:-2) ml. cach of zinc sullate and barium hvdroxicle. Ifter centrifugation, the precipitate was fincly suspended in $0.5 \mathrm{ml}$. of watlex and centrifuged. Ifter repeating the washing three times, the precipitate wa: resuspended in $0.2 \mathrm{ml}$. of water plus $0.1 \mathrm{ml}$. of 5. I sulfuic acid. 'The mixture was heated for 15 min. at log? cooled and neutralized with sodium livdrexide. Then $0.1 \mathrm{ml}$. each of barium hydroxisle and finc sulfate was added. After mixing and centrifuging. an aliquot of the supernatant was taken for the analysis of hexosamine.

\section{RESILTS}

\section{Phosphorylation by Lizer Extracts}

The phosphorylation of galactosamine could be regularly observed with crude liver homogenates prepared in water or saline solution. The activity of the supernatants obtained by high-speed centrifugation was still greater than that of the whole homogenates. Alter a lew hours at room temperature the activity clisappeared completely. At $10^{\circ}$ the crucle or purified extracts became inactive atter 34 days. Addlition of cysteine did not allect the activity.

As shown in Table $\mathbf{I}$, the purified extracts catalyze the phosphorylation of galactose and galactosamine to an equal extcrit and also that of fructose. The action on glucose is : mall and decreases with longer times of inabation, probably owing to the action of i hosphatase. A weak action on glucosamine ras also detected. Tests for other enzymes in these extracts revealed a weak phosphoglucomutase and glucose- 6 - phosphatase, and no action on galactose 1-phosphate, even after the addition of uricline diphosphate glucose (II)PG) ${ }^{16}$.

The $\mathrm{pH}$ optinum curves for the phosphorylation of galactose and galactosamine appear in Fig. 1. The galactose curve shows a sharp peak at $\mathrm{pH} 7.7$, while the galactosamine curve shows a broad maximum at $\mathrm{pH}$ 7.7 while the galactosamine curve shows a broad maximum at $\mathrm{pH}$ 7.3. The curve for the optimum concentration of magnesium ions appears in Fig. 2. The curves obtained with or without fluoricle are nearly equal. Maximal activity was obtained at about $0.0 \mathrm{I} \mathrm{M}$ concentration.

\section{Crossed Inhibition with the}

\section{Liver Enzyme}

An experiment on the phosphorylation of galactose and galactosamine mixtures is shown in Table II. For comparison, the phosphorylation of fructose, which is known to be catalyzed by a specilic enzyme ${ }^{17-19}$, was also studied. Estimations of fructose and galactosamine were carried out by the resorcinol and Elson-Morgan methods, respectively, and those of galactose by copper reduction and by difference in the mixed-sugar tests. Therefo$r e$, the results were very accurate.

TIBLE I

Phospluorvlation by Purified Liver Extracts

Incubation at $37^{\circ}$ of 0.5 pmole stigar, 2 pmoles ATP, and $0.1 \mathrm{ml}$. of $0.1 \mathrm{M}$ clisodium phosphate. Magnesium and fluoricle ions at $0.01 \quad M$ and 0.0 : $M$ final concentration, respectively; $0.05 \mathrm{ml}$. of purified liver enzyme. Total volume, $0.3 \mathrm{ml}, \mathrm{pH}$ 7.1.

$$
\text { Per cent of sugar phosphorvlated }
$$
Time of incubation, min.

$\begin{array}{lccccc}\text { Suldstrate } & 10 & 20 & 40 & 60 & 120 \\ \text { Galactose } & 43 & 64 & 73 & 81 & 253^{\mathrm{a}} \\ \text { Galactosamine } & 44 & 68 & 83 & 84 & 129 \\ \text { Fructose } & - & 43 & 90 & - & \\ \text { Glucose } & - & 29 & 29 & - & \end{array}$

4. With 0.2 $\mathrm{ml}$. of brain extract instead of liver cnzymic. 


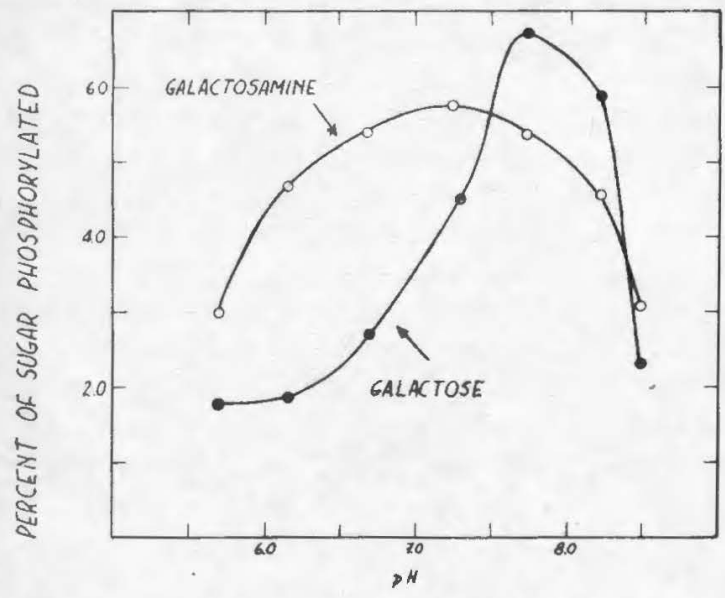

Fic. 1. - $\mathrm{pH}$ curve with the liver enzyme: $0.5 \mu$ mole sugar, $2 \mu$ moles ATP, $0.05 \mathrm{ml}$. enzyme, $0.10 \mathrm{ml}$. phosphate, $0.1 \mathrm{M} ; \mathrm{MgCl}_{2}$ and $\mathrm{NaF}$ in final concentration of 0.01 and $0.05 \mathrm{M}$, respectively. Final volume, $0.30 \mathrm{ml}$. The $\mathrm{pH}$ was determined aliquots with glass electrode; $30 \mathrm{~min}$. at $37^{\circ}$.

The results in Table II show that the rates of phosphorylation of fructose and galactosamine were approximately equal when the sugars were incubated separately or in mixtures. In the galactose-galäctosamine mixtures, phosphorylation was clearly slower than in the single-sugar experiments. The inhibition of galactosamine phosphorylation by galactose,

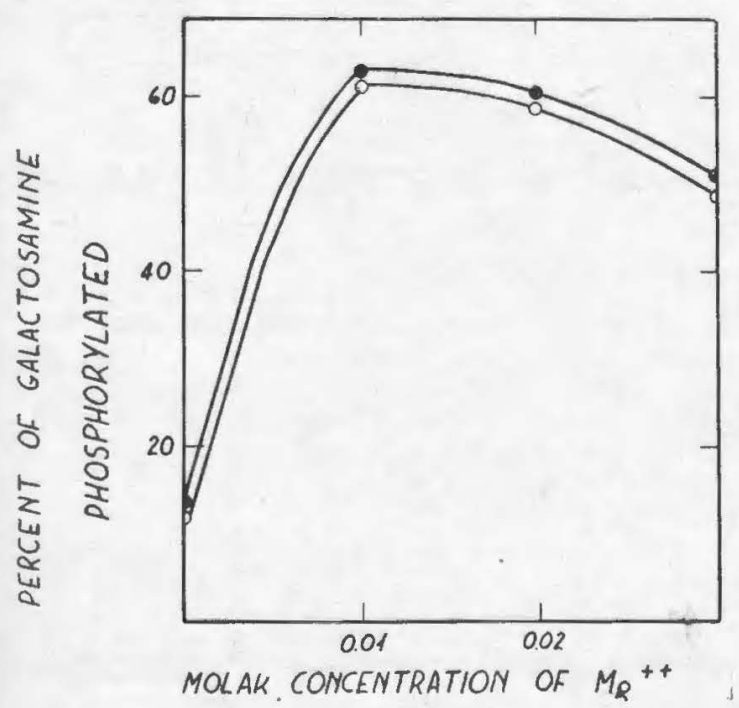

Fig. 2. - The effects of $\mathrm{Mg}++$ concentration on the liver enzyme: $0.5 \mu$ mole galactosamine, $2 \mu$ moles ATP, $0.025 \mathrm{ml}$. of liver enzyme. Final volume, $0.20 \mathrm{ml}$; 30 min. at $37 \%$. Lower curve with $0.05 M$ fluoride; upper curve: no fluoride.
TABLE II

\section{Phosphoryation of Sugar Mixtures by the} Liver Enzyme

Incubation at $37^{\circ}$ of $1 \mu$ mole sugar, $4 \mu$ moles ATP, $0.1 \mathrm{ml}$. of purified enzyme, and $0.1 \mathrm{ml}$. of $0.1 \mathrm{M}$ phosphate buffer of $\mathrm{pH}$ 7.2. Magnesium and fluoride ions at $0.01 M$ and $0.05 M$ final concentration, respectively. Final volume, $0.45 \mathrm{ml}$. The test with sugar mixtures contained $0.5 \mu$ mole of each sugar.

\begin{tabular}{lrcccc} 
& \multicolumn{4}{c}{ Per cent phosphorylation } \\
& Sugars & by & themselves & Mixed & sugars \\
Time of incubation, $\min 15$ & 30 & 15 & 30 \\
Galactosamine & 42 & 64 & 30 & 62 \\
Fructose & 42 & 62 & 42 & 55 \\
Gralactosamine & 43 & 72 & 0 & 0 \\
Galactose & 30 & 43 & 20 & 30
\end{tabular}

which is very marked, can be observed also in Fig. 3. Galactosamine phosphorylation was completely inhibited when the ratio of galac tosamine to galactose was lower than about 4 . On increasing the radio to about 8 , some galactosamine was phosphorylated, but the inhibition was still about $80 \%$.

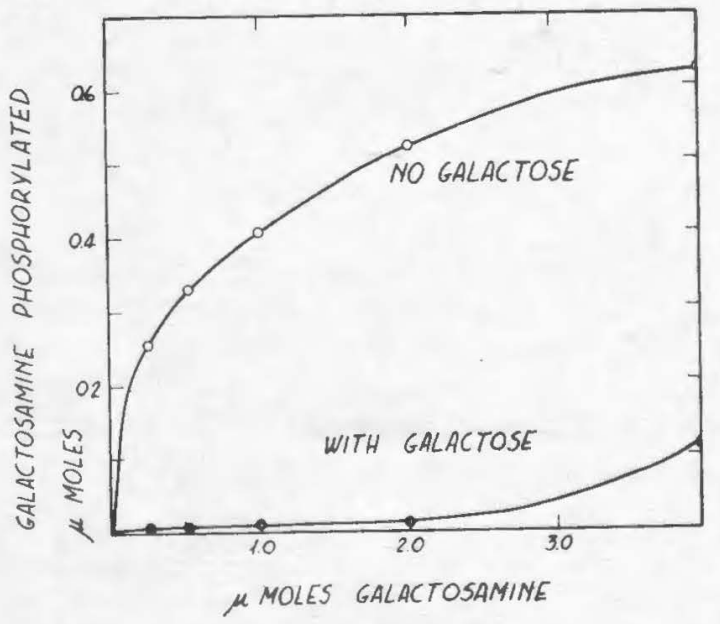

Fig. 3. - Galactosamine concentration curve and the inhibition by galactose $0.25 \mu$ mole galactose, 0.25 $4.0 \mu$ moles galactosamine, $2 \mu$ moles ATP $0.05 \mathrm{ml}$ of liver enzyme $\mathrm{MgCl}_{2}$ and $\mathrm{NaF}$ in $0.01 \mathrm{M}$ and $0.05 \mathrm{M}$ respectively, final concentration; $30 \mathrm{~min}$. at $37 \%$. Total volume, $0.3 \mathrm{ml}$.

\section{Phosphorilation by Extracts from Other Organs}

The action of brain extracts on both galactosamine and galactose was found to be weak but reproducible, especially in the case of galactosamine. The effect on galactose was 
only detected in tests carried out at a $\mathrm{pH}$ 7.7. The results shown in Table I were obtained with an extract of brain dried with acetone. With homogenates the resuls were irregular. No activity on galactosamine could be detected with extracts of kidney or intestinal mucosa.

\section{Phosphorylation with Yeast Extracts}

Extracts of brewer's yeast whick do not catalyze galactose phosphorylation at a detectable rate, were found to be devoid of action on galactosamine, whereas extracts of S. fragilis, which contain galactokinase were found to catalyze also galactosamine phosphorylation. An experiment was carried out in which extracts prepared from. S. fragilis grown in glucose or in lactose were compared in respect to their kinase activity. These results are shown in Table III. Galactokinase activity was nearly 20 -fold greater in the extract from the lactose-grown cells, as compared with that obtained from cells grown on glucose. The activity on galactosamine was also greater in extracts from lactose-grown cells. Accurate values for the ratio of activity on galactose and galactosamine in the two types of extracts could not be obtained owing to the low activity_in the extract from glucose grown cells.

\section{The Reaction Product}

Preliminary information on the type of ester formed was obtained from an experiment in which the reaction mixture was deproteinized whit trichloroacetic acid instead of zinc sulfate-barium hydroxide. The former reagent does no precipitate phosphoric esters as does the latter. Therefore, if the reducing group of the reaction products were blocked, the same decrease in amino sugar should be obtained with both procedures. This was found to be the case. Moreover, as shown in Table IV, after acid hydrolysis of the trichloroacetic acid filtrate, most of the amino sugar was set free.

\section{TABLE IV}

\section{Acid Hydrolysis of the Final Reaction Mixture}

Incubation at 379 for $30 \mathrm{~min}$, of $2 \mu$ moles galactosamine, $10 \mu$ moles ATP, $0.05 \mathrm{ml}$. of $0.9 \mathrm{M}$ sodium fluoride, $0.08 \mathrm{ml}$. of $0.1 \mathrm{M}$ magnesium chloride, and $0.2 \mathrm{ml}$. of purified liver enzyme. Final volume, $0.7 \mathrm{ml}$. Deproteinization with $20 \%$ trichloroacetic acid followed by estimation of galactosamine before and after hydrolysis with I $N$ hydrochloric acid at $100^{\circ}$ for $15 \mathrm{~min}$.

$\begin{array}{ccc}\begin{array}{c}\text { Time of } \\ \text { incubation } \\ \text { min. }\end{array} & \begin{array}{c}\text { Galactosamine } \\ \text { No hydrolysis } \\ \%\end{array} & \begin{array}{c}\text { percentage } \\ \text { Hydrolized } \\ \%\end{array} \\ 0 & 100 & 95 \\ 30 & 28 & 88\end{array}$

Nearly pure preparations of the reaction product were obtained from larger-scale experiments in which the sugar esters were purified by precipitation of the barium salts with ethanol and by removal of adenosine phosphates with mercuric nitrate. The procedure was essentially as described by Brown ${ }^{2}$. The

TABLE III

Phosphorylation with Extracts of Saccharomyces
fragilis

Incubation at 379 of $0.5 \mu$ mole sugar. $2 \mu$ mole ATP, $\mathrm{Mg}++$ at $0.01 \mathrm{M}$ final concentration, and extracted of $\mathrm{S}$. fragilis grown on lactose or on glucose. Final volume, $0.15 \mathrm{ml}$. Both enzyme solutions contained the same concentration of protein.

\begin{tabular}{|c|c|c|c|c|c|c|c|}
\hline $\begin{array}{l}\text { Sugar in } \\
\text { growth } \\
\text { medium }\end{array}$ & $\begin{array}{l}\text { Enzyme } \\
\text { dilution }\end{array}$ & $\begin{array}{c}\text { Amount } \\
\text { of enzyme } \\
\mathrm{ml} .\end{array}$ & Substrate & $\begin{array}{l}\text { Time } \\
10 \\
\text { Micre } \\
\text { pl }\end{array}$ & $\begin{array}{l}f \text { incubs } \\
\text { min. } \\
20 \\
\text { les of } \\
\text { phorylate }\end{array}$ & & Activity * \\
\hline Lactose & None & 0.01 & Galactosamine & 0.035 & 0.09 & 0.22 & 0.75 \\
\hline Lactose & $1 / 50$ & 0.03 & Galactose & 0.32 & 0.39 & 0.46 & 53 \\
\hline Lactose & $1 / 500$ & 0.05 & Glucose & 0.25 & 0.31 & 0.5 & 250 \\
\hline Glucose & None & 0.01 & Galactosamine & 0.045 & 0.045 & 0.06 & 0.2 \\
\hline Glucose & $1 / 50$ & 0.03 & Galactose & 0.035 & 0.035 & 0.05 & 2.8 \\
\hline Glucose & $1 / 500$ & 0.05 & Glucose & 0.35 & 0.5 & 0.5 & 350 \\
\hline
\end{tabular}

- Expressed in micromoles phosphorylated $/ \mathrm{min} . / \mathrm{ml}$. of undiluted enzyme solution. 


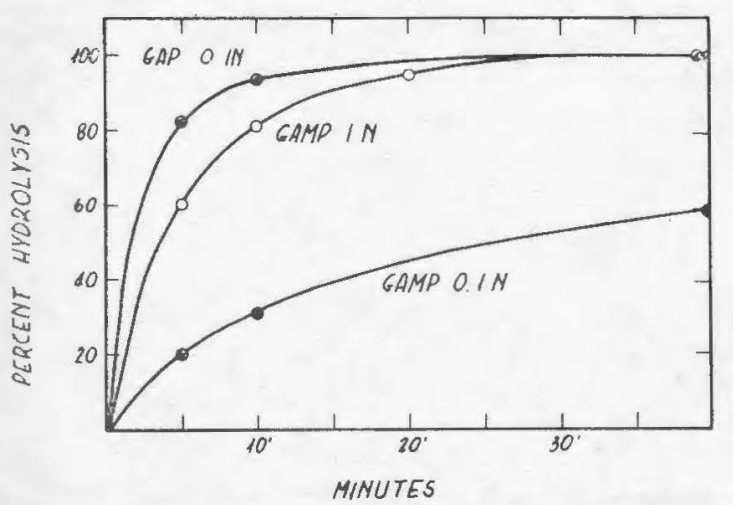

Fig. 4. - Hydrolysis curve of the galactosamine ester. Liberation of phosphate after heating at $100^{\circ}$ in acid. GAMP: galactosamine ester. GAP: galactose 1phosphate.

product thus obtained from galactosamine using the liver enzyme contained no inorganic phosphate and gave no Elson-Morgan reaction. After hydrolysis in $1 \mathrm{~N}$ acid at $100^{\circ}$ for 15 min., equal amounts of phosphate and amino sugar were set free.

The product obtained from galactose using the liver enzyme was nonreducing and gave by acid hydrolysis equal amounts of phosphate and reducing sugar. Thus it appears to be galactose 1-phosphate.

Products with the same properties were obtained using extracts of $S$. fragilis. Since smaller amounts of enzyme were required, less extraneous material was introduced, and the products were purer. The acid hydrolysis curve of the galactosamine ester is shown in Fig. 4. The same results were obtained by estimating phosphate or galactosamine.

The hydrolysis of the galactosamine ester is much slower than that of the galactose ester Even in $1 \mathrm{~N}$ acid it does not reach the rate obtained with galactose phosphate in $0.1 \mathrm{~N}$ acid.

\section{Discussion}

The problem of whether galactosamine phosphorylation is brought about by galactokingase or by a specific enzyme cannot be answered with certainty, although the evidence is in favor of a single enzyme. With the liver enzyme there is crossed inhibition, the relative activities are approximately equal in different samples of liver, and both activities disappear on storage at about the same rate. - Moreover, the phosphate group appears to be introduced in the 1-position in both cases. The $\mathrm{pH}$-optimum curves are different, but this does not prove that two enzymies are involved. With the liver enzyme both activities are approximately equal at $\mathrm{pH} 7.5$, whereas with the $S$. fragilis enzyme, the activity on galactose is higher than on galactosamine.

In $S$. fragilis the galactosamine activity increases during growth on a galactose-containing medium (lactose), but even this is no proof for a single enzyme, since in other organisms it has been found that substances different from the substrate may induce the formation of the enzyme ${ }^{20}$.

If it is accepted that galactosamine phosphorylation is catalyzed by galactokinase, the results would be of interest because the measurement of galactosamine phosphorylation would give an estimate of galactokinase activity. This estimate cannot be obtained with galactose in crude liver extracts awing to the interference by other reducing substances. Since there is no such interference when using galactosamine, it would be possible to compare the galactokinase activity of liver samples in cases where galactose metabolim is impaired, such as in galactosemia.

A point of interest in relation to galactosamine 1-phosphate is its resistance to acid hydrolysis. Such a resistance has been observed in glucosaminides [see Ref. (21) for a discussion of this].

\section{Summary}

The transfer of phosphate from adenosine triphosphate to galactosamine was found to be catalyzed by a liver enzyme. On the basis of the parallel distribution and from crossed inhibition experiments it is suggested that enzyme may be galactokinase.

The optimum conditions for activity and a method for partial purification are described.

Phosphorylation of galactosamine and of galactose was also found to be catalyzed by 
extracts from brain tissue and from a lactose yeast (Saccharomyces fragilis). Extracts from cells of the latter grown lactose, which cells contain more galactokinase, were found to have higher activity on galactosamine.

\section{REFERENCES}

1. Harpur, R. P., AND Quastel, J. H., Nature 164 , 693 (1949).

2. Brown, D. H., Biochim. et Biophys. Acta y, 487 (1951).

3. Grant, P. T., AND Long, G., Biochem. J. (London) 50, xx (1952).

4. Bacila, M., Arquiv. biol. e tecnol. Inst. biol. $e$ pesquisas tecnol. 3, 3 (1915).

5. Trucco, R. E., Caputto, R., Lelotr, L. F., AND Mittelman, N., Arch Biochem. 18, 137 (1948).

6. Wilkinson, J. F., Biochem. J. (London) 44, 460 (1949).

7. Nyurerg, C., ANd Lustig, H., Arch. Biochem. 1, 191 (1942).

8. Levene, P. A., Hexosamises and Mucoproteins. Longmans, Green, London, 1925.

9. Needham D. M., Biochem. J. (London) 36, 113. (1942).

10. Blix, G., Acta Chem. Scand. 2, 467 (1948).
Evidence is presented indicating that the reaction products is galactosamine 1-phosphate. This product was found to be more resistant to acid hydrolysis than aldose 1-phosphates.
11. Roe, J. H., J. Biol. Chem. 107, 15 (1934)

12. Fiske, C. H., and Subra Row, Y., J. Biol. Chem. 66 , $375(1925)$.

13. Kunitz, M., And McDonald, M., J. Gen. Physiol, 29, 411 (1945).

14. Somogyi, M., J. Biol. Chem. 160, 61, 69 (1945).

15. Nelson, N., J. Biol. Chem. 153, 375 (1944).

16. Cardini, C. E. Paladini, A. C., Caputto, R., and LELOIR, L. F., Nature 165, 191 (1950); CAPUTto, R., Leloir, L. " Cardini, C. E, and Paladini, A- C., J. Biol. Chem. 184, 333 (1950).

17. Sterin, M. W., Cori, C. F., J. Biol. Chem. 186763 $(1950)$.

18. Liuthardt, $F$., And Testa, E., Helv. Chim. Acta 33, $1919(1950)$.

19. Staed, A., and Vestiling, C. S., J. Biol. Chem. 191, 395 (I951).

20. Monod, J., Cohen-Bazrre, G., and Cohn, M., Biochim. et Biophys. Acta y, 585 (1951).

21. Viscontini, M., and Meier, J., Helv. Chim. Acta 35, 807 (1952). 